\title{
ИНТЕГРАЛЬНЫЕ ЭКОЛОГИЧЕСКИЕ ИНДЕКСЫ КАК АНАЛИТИЧЕСКИЙ ИНСТРУМЕНТ ОЦЕНКИ РЕЗУЛЬТАТИВНОСТИ ДЕЙСТВИЙ В ПРИРОДООХРАННОЙ СФЕРЕ
}

\author{
О.Н. Лопачук
}

\begin{abstract}
Рассмотрены и систематизированы интегральные индексы, содержащие экологические параметры. Исследованы структура, индикаторы и методы построения тематических экологических индексов, которые характеризуют воздействие на окружающую среду и здоровье человека, а также адаптацию к климатическим изменениям. Дан обзор источников исходных данных для расчета тематических экологических индексов. На основе анализа положения Беларуси в международных рейтингах выявлен спектр проблем и достижений нашей страны в природоохранной сфере.
\end{abstract}

Ключевые слова: индекс, индикатор, климатические изменения, состояние окружающей среды, экологические рейтинги.

JEL-классификация: Q51, C43.

DOI: $10.46782 / 1818-4510-2021-3-100-112$

Материал поступил 7.09.2021 2.

В последние десятилетия важным инструментом оценки прогресса стран в сфере сохранения благоприятной окружающей среды, устойчивого развития, движения в сторону «зеленой» экономики, реализации ответственной климатической политики и экологической безопасности стали интегральные индексы, в соответствии с которыми составляются рейтинги стран, проводятся международные сопоставления, исследуются национальные особенности (Алексеева, Аршинова, Банчева, 2018; Батова, 2018; Диденко, 2020; Саушева, 2020).

С одной стороны, привлекательность интегральных индексов как результирующих индикаторов состояния и/или функционирования сложных социо-эколого-экономических систем очевидна: они наглядны и легко интерпретируемы, с их помощью эффективно осуществляется коммуникация между специалистами и потребителями информации, привлекается внимание общественности к определенным экологическим угрозам. С дру- гой стороны, адекватность параметров представления взаимосвязанных экономических, экологических и социальных составляющих общественного развития и определение значимости исходных показателей при агрегировании информации в индексы формируют широкое проблемное поле.

Разработкой интегральных индексов и составлением на их основе международных рейтингов занимается ряд университетов, научных коллективов, коммерческих компаний, а также международных организаций и сетей. Проведенный анализ позволяет сгруппировать интегральные индексы, содержащие экологические параметры, следующим образом:

- тематические экологические индексы, которые в зависимости от предмета оценки характеризуют: 1) воздействие на окружающую среду и здоровье человека через загрязнение и потребление природного капитала (индекс экологической эффективности, экологический след, индекс живой планеты, ин-

* Лопачук Ольга Николаевна (lopachuk@mail.ru), кандидат экономических наук, доцент, Белорусский государственный экономический университет (г. Минск, Беларусь). https://orcid.org/0000-0003-3753-0876 
декс загрязнения и др.); 2) уязвимость к климатическим изменениям и эффективность реагирования на них (индекс климатического риска, индекс эффективности действий в области изменения климата, индекс адаптации к изменениям климата); 3) экологические права граждан (индекс экологической демократии);

- индексы общественного развития и социального благополучия с учетом экологической составляющей (индекс человеческого развития с учетом планетарной нагрузки, индекс социального прогресса, индекс процветания, индекс устойчивого общества, глобальный индекс инноваций, индекс лучшей жизни, международный индекс счастья и др.);

- эколого-экономические индексы, в которых экологически скорректированы или адаптированы экономические показатели (индекс адаптированных чистых сбережений, индекс истощения природных ресурсов и др.);

- индексы, отражающие прогресс в сфере «зеленой» экономики (глобальный индекс «зеленой» экономики, индекс «зеленого» роста, инновационный индекс экологически чистых технологий, индекс низкоуглеродной экономики и др.).

Рассматрим только тематические экологические индексы и соответствующие системы рейтингов, в которых приводятся межстрановые сопоставления, что позволяет выявить позицию Республики Беларусь относительно других государств. Методологический интерес в анализе экологических индексов представляют экспертный выбор или конструирование наиболее информативных переменных - индексов состояния /воздействия на окружающую среду; определение весовых коэффициентов и подходов к агрегированию разнородных (многокритериальных) оценок с учетом их вклада в общую оценку.

\section{Структура, индикаторы и методы построения интегральньх әкологических индексов}

Одними из наиболее общепризнанных и авторитетных в мире являются совместные методические разработки Йельского и Колумбийского университетов, воплотивши- еся в индексе экологической устойчивости (Environmental Sustainability Index - ESI, представлен на Всемирном экономическом форуме в Давосе, 2001 г.) и заменившем его индексе экологической эффективности (Environment Performance Index - EPI, 2006 г.).

Многоуровневый индекс EPI состоит из двух укрупненных частей: благоприятность окружающей средь для здоровья человека (Environmental Health) и жизнестойкость экосистем (Ecosystem Vitality), каждая из которых конкретизируется по стратегическим категориям, а далее - по количественным показателям с использованием 100-балльной шкалы (100 - высший результат, 0 - низший) и весовых коэффициентов (Hsu, de Sherbinin, Esty, Levy, 2016; Wendling, Emerson, de Sherbinin, Esty, 2020). При построении пилотного EPI 2006 использовались 16 показателей, сгруппированных по 6 стратегическим категориям; расчет индекса EPI 2008 осуществлялся на основе 25 показателей; для EPI 2020 использовано 32 показателя, сгруппированных по 11 стратегическим категориям при сохранении двух укрупненных частей: благоприятность окружающей среды для здоровья человека и жизнестойкость экосистем (рис. 1, табл. 1).

На первоначальном этапе составления индекса показатели оцениваются по шкале от 0 до 100, для их трансформации используется алгоритм min-max: значение индикатора $=(($ показатель страны - нижняя граница) / (верхняя граница - нижняя граница)) × 100\%. При этом под верхней границей понимается заданный высокий показатель выборки: для его определения прибегают к докладам международных организаций, использованию экспертных опросов или выбирают 95 или 99 перцентиль. Все веса задаются методом экспертной оценки, что позволяет сохранить прозрачность методологии, однако делает ее более субъективной.

Широко известным методом комплексной оценки спроса на природный капитал и чрезвычайно популярным индикатором является Экологический след (The Ecological Footprint), позволяющий сопоставлять биологически продуктивную территорию, которую люди используют для своего потребления, с биологической емкостью природной 
О.Н. ЛОПАЧУК

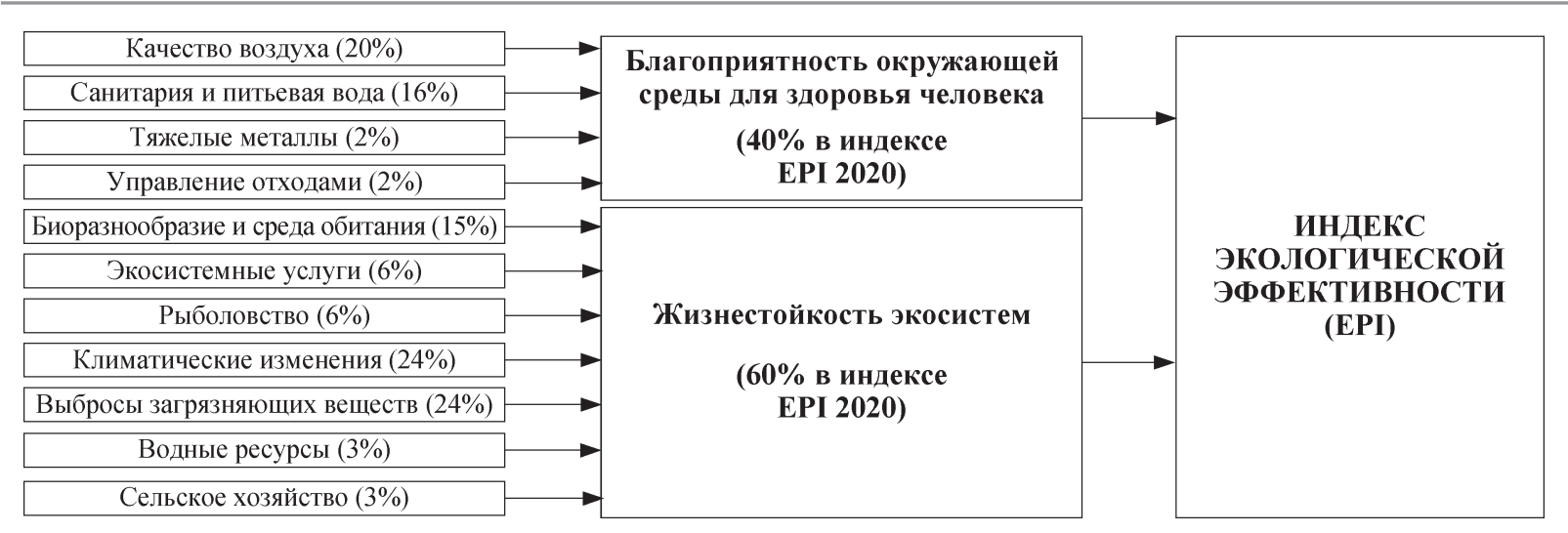

Рис. 1. Структура индекса экологической эффективности, 2020

Источник. Авторская разработка на основе (Wendling, Emerson, de Sherbinin, Esty, 2020).

Индикаторы Индекса экологической эффективности (ЕР-2020)

Таблица 1

\begin{tabular}{|c|c|c|c|}
\hline Категория & Bec, \% & Индикаторы & Bec, \% \\
\hline \multicolumn{4}{|c|}{ Благоприятность окружающей среды для здоровья человека } \\
\hline \multirow[t]{3}{*}{ Качество воздуха } & \multirow{3}{*}{20} & Мелкодисперсные взвешенные частицы $\mathrm{PM}_{2.5}$ & 11 \\
\hline & & Использование твердого топлива в домохозяйствах & 8 \\
\hline & & Воздействие озона & 1 \\
\hline \multirow{2}{*}{$\begin{array}{l}\text { Санитария и питьевая } \\
\text { вода }\end{array}$} & \multirow{2}{*}{16} & Качество питьевой воды & 9,6 \\
\hline & & Качество санитарии & 6,4 \\
\hline Тяжелые металлы & 2 & Воздействие свинца & 2 \\
\hline Управление отходами & 2 & Контролируемые твердые отходы & 2 \\
\hline \multicolumn{4}{|c|}{ Жизнестойкость экосистем } \\
\hline \multirow{7}{*}{$\begin{array}{l}\text { Биоразнообразие } \\
\text { и среда обитания }\end{array}$} & \multirow{7}{*}{15} & Состояние биомов & 3 \\
\hline & & Защита наземных биомов & 3 \\
\hline & & Морские охраняемые территории & 3 \\
\hline & & Индекс особо охраняемых природных территорий & 1,5 \\
\hline & & Индекс защиты видов & 1,5 \\
\hline & & Индекс биоразнообразия среды обитания & 1,5 \\
\hline & & Индекс разнообразия видов & 1,5 \\
\hline \multirow[t]{3}{*}{ Экосистемные услуги } & \multirow{3}{*}{6} & Утрата древесного покрова & 5,4 \\
\hline & & Утрата пастбищ & 0,3 \\
\hline & & Утрата водно-болотных угодий & 0,3 \\
\hline \multirow[t]{3}{*}{ Рыболовство } & \multirow{3}{*}{6} & Состояние рыбных запасов & 2,1 \\
\hline & & Рыба, пойманная тралением & 1,8 \\
\hline & & Морской трофический индекс & 2,1 \\
\hline \multirow{8}{*}{$\begin{array}{l}\text { Климатические } \\
\text { изменения }\end{array}$} & \multirow{8}{*}{24} & Темпы роста выбросов $\mathrm{CO}_{2}$ & 13,2 \\
\hline & & Темпы роста выбросов $\mathrm{CH}_{4}$ & 3,6 \\
\hline & & Темпы роста выбросов фторсодержащих газов & 2,4 \\
\hline & & Темпы роста выбросов $\mathrm{N}_{2} \mathrm{O}$ & 1,2 \\
\hline & & Темпы роста выбросов СО & 1,2 \\
\hline & & $\begin{array}{l}\text { Темпы роста выбросов } \mathrm{CO}_{2} \text { в результате изменения } \\
\text { растительного покрова }\end{array}$ & 0,6 \\
\hline & & Тренд интенсивности выбросов парниковых газов & 1,2 \\
\hline & & Выбросы парниковых газов на душу населения & 0,6 \\
\hline \multirow{2}{*}{$\begin{array}{l}\text { Выбросы загрязняющих } \\
\text { веществ }\end{array}$} & \multirow[b]{2}{*}{3} & Темпы роста выбросов $\mathrm{S}_{2} \mathrm{O}$ & 1,5 \\
\hline & & Темпы роста выбросов $\mathrm{N}_{\mathrm{x}} \mathrm{O}$ & 1,5 \\
\hline Водные ресурсы & 3 & Очистка сточных вод & 3 \\
\hline Сельское хозяйство & 3 & Индекс устойчивого управления азотом & 3 \\
\hline
\end{tabular}

Источник. Авторская разработка на основе (Wendling, Emerson, de Sherbinin, Esty, 2020). 
среды в пределах страны, региона или мира. Концепция экологического следа была предложена в начале 1990-х годов М. Вакернагелем и В. Ризом (Университет Британской Колумбии) (Wackernagel, Rees, 1996), а в 2003 г. с целью согласования методологии и координации исследований по этому направлению М. Вакернагель создал международную исследовательскую организацию «Глобальная сеть экологического следа» («Global Footprint Network»), поддерживаемую в настоящее время Всемирным фондом дикой природы и длинным списком национальных и местных экологических организаций, а также исследовательских институтов (www.footprintnetwork.org.).

Согласно классической методологии М. Вакернагеля и В. Риза, экологчческий след представляет собой площадь биологически продуктивной территории и акватории, необходимой для производства ресурсов и поглощения отходов, и рассчитывается как сумма шести слагаемых: площадь застроенных земельных участков; площадь лесов для поглощения $\mathrm{CO}_{2}$; площадь пахотных земель для производства продукции растениеводства; акватория водных объектов для производства морепродуктов и ловли рыбы; площадь лесов для получения древесины и другой лесной продукции; площадь пастбищ для производства продуктов животноводства и кормов для скота. Биоемкость связана с несущей способностью территории и отражает площадь биологически продуктивных территорий и акваторий, способных обеспечивать человека ресурсами и поглощать отходы. Результаты измерения экологического следа и биоемкости выражаются в универсальных стандартизованных единицах - глобальных гектарах (гга) со среднемировым показателем биологической продуктивности (Ewing, Moore, Goldfinger, Oursler, Reed, Wackernagel, 2010; Borucke, Moore, Cranston, Gracey, Iha, Larson, Lazarus, Morales, Wackernagel, Galli, 2013; Lin, Hanscom, Martindill, Borucke, Cohen, Galli, Lazarus, Zokai, Iha, Eaton, Wackernagel, 2019). Если экологический след больше, чем биоемкость, то страна имеет экологический дефицит, который указывает на то, что потребление людей превышает способность природной среды обеспечить такой уровень.

Для оценки способности стран мира противостоять угрозам глобального потепления экспертами Программы Инициативы по изменению окружающей среды американского Университета Нотр-Дамм разработан индекс глобальной адаптации (The Notre Dame Global Adaptation Index, ND-GAIN), рейтинги которого публикуются ежегодно начиная с 1995 г. Индекс сфокусирован на двух ключевых аспектах: во-первых, насколько чувствительна страна к изменениям климата, учитывая ее собственный климат и население, инфраструктуру и т. п.; вовторых, насколько готова она принять соответствующие риски в рамках своего политического, экономического и социального положения (Chen, Noble, Hellmann, Coffee, Murillo, Chawla, 2015).

Соответственно, для формирования индекса ND-GAIN определяются 36 индикаторов уязвимости (Vulnerability Indicators) и 9 индикаторов готовности (Readiness Indicators) (рис. 2, табл. 2), которые масштабируются по-

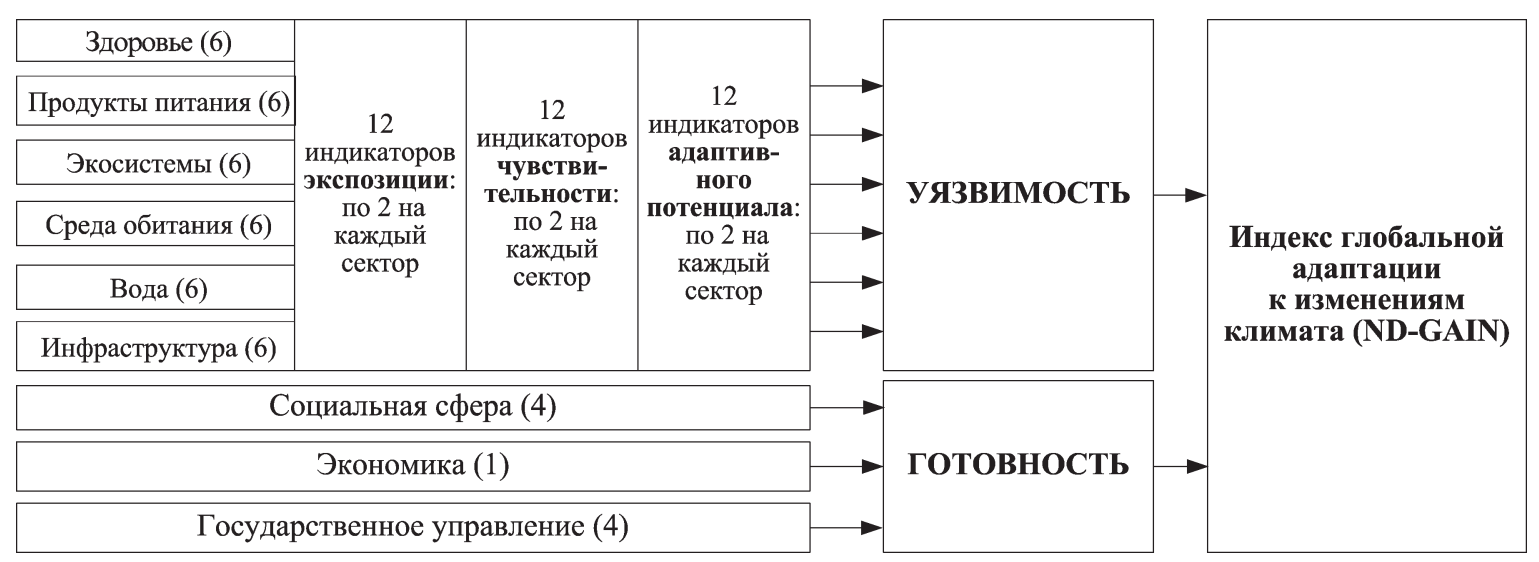

Рис. 2. Структура Индекса глобальной адаптации к изменениям климата

Источник. Авторская разработка на основе (Chen, Noble, Hellmann, Coffee, Murillo, Chawla, 2015). 
Индикаторы Индекса глобальной адаптации к изменениям климата (ND-GAIN)

\begin{tabular}{|c|c|c|c|}
\hline Сектор & Индикаторы воздействия & $\begin{array}{c}\text { Индикаторы } \\
\text { чувствительности }\end{array}$ & $\begin{array}{c}\text { Индикаторы потенциала } \\
\text { адаптации }\end{array}$ \\
\hline \multicolumn{4}{|c|}{ Индикаторы уязвимости } \\
\hline \multirow[t]{2}{*}{ Еда } & $\begin{array}{l}\text { Прогнозируемое изменение } \\
\text { урожайности зерновых (рис, } \\
\text { пшеница, кукуруза) }\end{array}$ & $\begin{array}{l}\text { Импорт продуктов } \\
\text { питания }\end{array}$ & $\begin{array}{l}\text { Потенциал сельского } \\
\text { хозяйства (удобрения, } \\
\text { орошение, пестициды, } \\
\text { сельскохозяйственная } \\
\text { техника }\end{array}$ \\
\hline & $\begin{array}{l}\text { Прогнозируемое изменение } \\
\text { численности населения }\end{array}$ & Сельское население & Детское недоедание \\
\hline \multirow[t]{2}{*}{ Вода } & $\begin{array}{l}\text { Прогнозируемое изменение } \\
\text { годового стока }\end{array}$ & $\begin{array}{l}\text { Сокращение запасов } \\
\text { пресной воды }\end{array}$ & $\begin{array}{l}\text { Доступ к чистой питьевой } \\
\text { воде }\end{array}$ \\
\hline & $\begin{array}{l}\text { Прогнозируемое изменение } \\
\text { ресурсов подземных вод }\end{array}$ & $\begin{array}{l}\text { Коэффициент } \\
\text { зависимости от воды }\end{array}$ & $\begin{array}{l}\text { Пропускная способность } \\
\text { плотин }\end{array}$ \\
\hline \multirow[t]{2}{*}{ Здоровье } & $\begin{array}{l}\text { Прогнозируемое изменение } \\
\text { смертности от изменения климата }\end{array}$ & Население трущоб & $\begin{array}{l}\text { Численность медицинского } \\
\text { персонала }\end{array}$ \\
\hline & $\begin{array}{l}\text { Прогнозируемое изменение } \\
\text { болезней из-за увеличения } \\
\text { сезона передачи }\end{array}$ & $\begin{array}{l}\text { Зависимость } \\
\text { медицинских услуг от } \\
\text { внешних ресурсов }\end{array}$ & $\begin{array}{l}\text { Доступ к улучшенным } \\
\text { санитарно-техническим } \\
\text { средствам }\end{array}$ \\
\hline \multirow[t]{2}{*}{ Экосистемы } & $\begin{array}{l}\text { Прогнозируемое изменение } \\
\text { распределения наземных биомов }\end{array}$ & $\begin{array}{l}\text { Зависимость от } \\
\text { природного капитала }\end{array}$ & Защищенные биомы \\
\hline & $\begin{array}{l}\text { Прогнозируемое изменение } \\
\text { морского разнообразия }\end{array}$ & Экологический след & $\begin{array}{l}\text { Участие в международных } \\
\text { природоохранных } \\
\text { конвенциях }\end{array}$ \\
\hline \multirow[t]{2}{*}{$\begin{array}{l}\text { Среда обитания } \\
\text { человека }\end{array}$} & $\begin{array}{l}\text { Прогнозируемое изменение } \\
\text { теплого периода }\end{array}$ & Уровень урбанизации & $\begin{array}{l}\text { Качество торговой } \\
\text { и транспортной } \\
\text { инфраструктуры }\end{array}$ \\
\hline & $\begin{array}{l}\text { Прогнозируемое изменение } \\
\text { наводнений }\end{array}$ & $\begin{array}{l}\text { Доля людей } \\
\text { пенсионного возраста }\end{array}$ & Асфальтированные дороги \\
\hline \multirow[t]{2}{*}{ Инфраструктура } & $\begin{array}{l}\text { Прогнозируемое изменение } \\
\text { гидроэнергетики }\end{array}$ & $\begin{array}{l}\text { Зависимость от } \\
\text { импортируемой } \\
\text { энергии }\end{array}$ & Доступ к электричеству \\
\hline & $\begin{array}{l}\text { Повышение уровня мирового } \\
\text { океана }\end{array}$ & $\begin{array}{l}\text { Население, проживающее } \\
\text { в } 5 \text { м над уровнем } \\
\text { моря }\end{array}$ & $\begin{array}{l}\text { Готовность к стихийным } \\
\text { бедствиям }\end{array}$ \\
\hline \multicolumn{4}{|c|}{ Индикаторы готовности } \\
\hline Экономика & \multicolumn{3}{|c|}{ Ведение бизнеса (составлен из 10 субиндикаторов) } \\
\hline Социальная сфера & Социальное неравенство & $\begin{array}{l}\text { Образование } \\
\text { Инфраструктура ИКТ }\end{array}$ & Инновации \\
\hline $\begin{array}{l}\text { Государственное } \\
\text { управление }\end{array}$ & Политическая стабильность & $\begin{array}{l}\text { Верховенство закона } \\
\text { Борьба с коррупцией }\end{array}$ & Качество управления \\
\hline
\end{tabular}

Источник. Авторская разработка на основе (Chen, Noble, Hellmann, Coffee, Murillo, Chawla, 2015).

средством процедуры нормализации min-max значений в интервале от 0 до 1.

Вычисление итогового индекса ND-GAIN проводится по формуле: (среднее арифметическое индикаторов готовности - среднее арифметическое индикаторов уязвимости +1$) \times 50$.

Индекс эффективности действий в области изменения климата (Climate Change Performance Index, CCPI), разработанный НПО «Немецкая Наблюдательная Инициатива» (Germanwatch) (Германия) в сотрудничестве с Международной Сетью климатических действий (Climate Action Network International), был впервые опубликован в
2005 г., а его обновленная версия ежегодно представляется на Конференции ООН по изменению климата.

В 2017 г. методология CСРІ была актуализирована в контексте целей Парижского климатического соглашения (2015 г.), в частности сдерживания роста глобальной средней температуры ниже $2^{\circ} \mathrm{C}$ (Burck, Hagen, Höhne, Nascimento, Bals, 2020).

Национальные достижения оцениваются по 14 взвешенным показателям в четыpex категориях: 1) выбросы парниковых газов $(40 \%) ; 2)$ возобновляемая энергия (20\%); 3) энергопотребление (20\%); 4) климатическая политика (20\%) (рис. 3). 


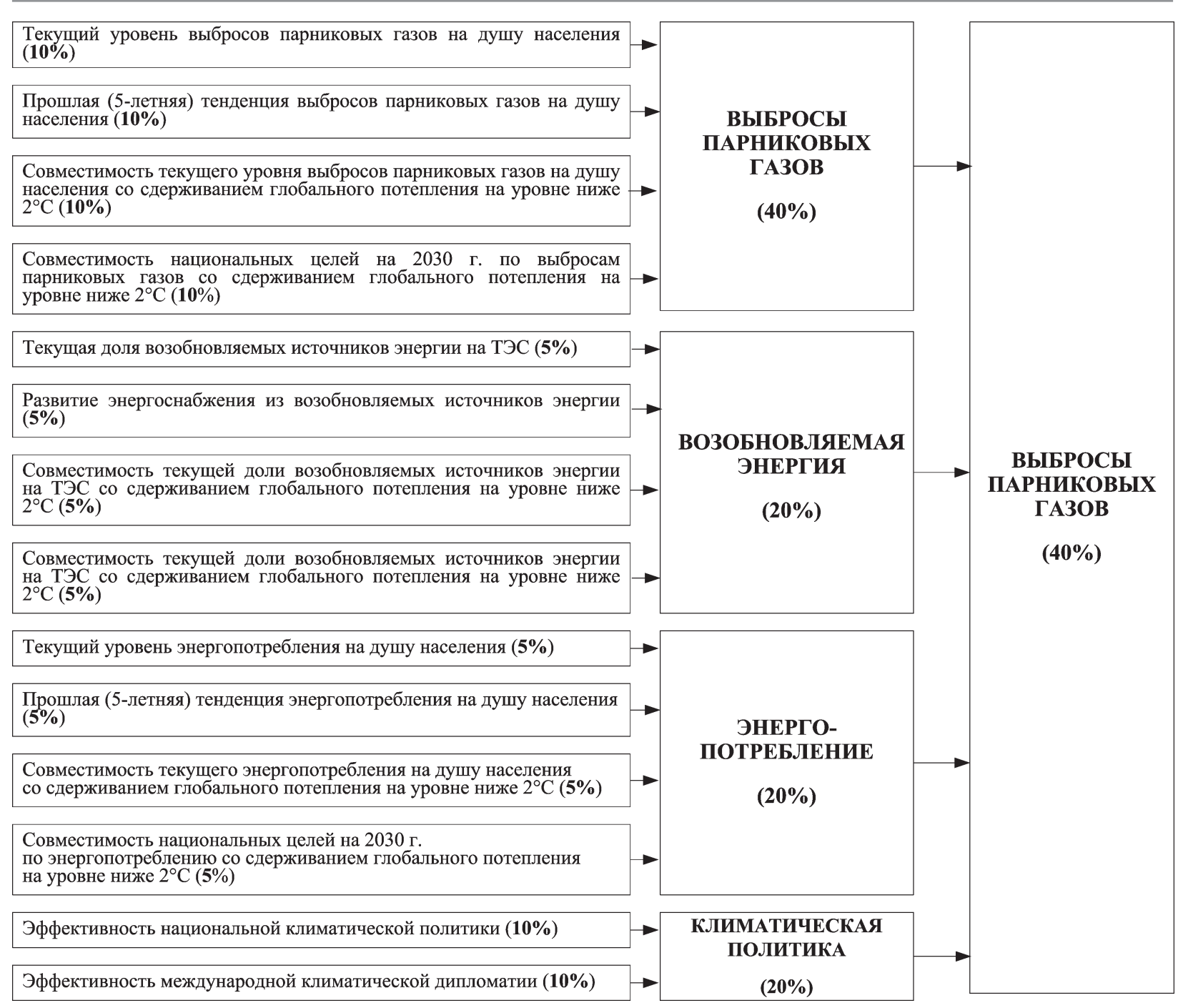

Рис. 3. Структура Индекса эффективности действий в области изменения климата Источник. Авторская разработка на основе (Burck, Hagen, Нцhne, Nascimento, Bals, 2020).

При этом 80\% оценки эффективности действий стран в области изменения климата основаны на количественных данных, остальные $20 \%$ (категория «Климатическая политика») оцениваются экспертным путем как очень высокие, высокие, средние, низкие или очень низкие. Исходя из долгосрочных целей Парижского климатического соглашения, контрольными показателями являются: нулевые выбросы парниковых газов, 100\%-я энергия из возобновляемых источников и сохранение сегодняшнего среднего глобального уровня энергопотребления на душу населения. Согласно CCPI, ни одна из стран еще не достигла результатов по всем показателям, которые можно квалифицировать как очень высокие, поэтому первые три места в итоговом рейтинге всегда остаются незанятыми.
Изменение климата повышает вероятность возникновения и интенсивность воздействия экстремальных погодных явлений, таких как штормы, наводнения и аномальная жара / холод. Так, в результате более 11000 экстремальных погодных явлений 2000-2019 гг. в мире погибло более 475000 чел., а убытки составили 2,56 трлн долл. США (по ППС) (Eckstein, Künzel, Schäfer, 2021). Kоличественные последствия экстремальных погодных явлений - как с точки зрения числа погибших, так и с точки зрения экономического ущерба - анализирует Глобальный индекс климатических рисков (Global Climate Risk Index CRI), разработанный НПО «Немецкая Наблюдательная Инициатива» (Germanwatch) (Германия).

Для его составления страны ранжируются по следующим показателям: 
1) количество погибших;

2) количество погибших на 100000 жителей;

3)экономический ущерб в долларах США по ППС; ВВП.

4) экономический ущерб на единицу

Итоговый индекс CRI представляет сумму рангов страны по всем четырем показателям с заданными весовыми коэффициентами: количество погибших $-1 / 6$; количество погибших на 100000 жителей - 1/3; экономический ущерб - 1/6; экономический ущерб на единицу ВВП - 1/3. Например, в Индексе климатических рисков за 2000-2019 гг. Беларусь занимает 136 место по количеству погибших среди всех стран, проанализированных в этом исследовании, 161 - по количеству погибших на 100000 жителей, 145 по экономическому ущербу и 167 - по экономическому ущербу на единицу ВВП. Следовательно, национальный индекс CRI pacсчитывается следующим образом: $\mathrm{CRI}=$ $136 \times 1 / 6+161 \times 1 / 3+145 \times 1 / 6++167 \times 1 /$ $3=156,17$.

Очевидно, что индекс CRI не претендует на всеобъемлющий анализ рисков антропогенного изменения климата. В частности, он не учитывает важные долгосрочные процессы, такие как повышение уровня моря, таяние ледников или потепление и подкисление океана. Геологические происшествия, такие как землетрясения, извержения вулканов или цунами, последствия от которых значительны, также не имеют значения в данном контексте, поскольку они не зависят от метеорологических последствий и, следовательно, не могут быть связаны с изменением климата. Кроме того, данные отражают только прямые последствия (прямой экономический ущерб и смертельные случаи) экстремальных погодных явлений, в то время как косвенные последствия (например, нехватка продовольствия в результате засух) не учитываются.

Загрязнение окружающей среды в странах и городах на основе базы данных, создаваемой по результатам социологического опроса посетителей сайта https:// www.numbeo.com/(Сербия), а также при необходимости отдельных показателей ВОЗ и ряда экологических организаций, оценивается Индексом загрязнения (Pollution Index). Каждая запись в опросе сохраняется как число в диапазоне [-2, +2], где -2 означает строго отрицательное значение, а +2 - строго положительное, и для представления результатов опроса используется 100-балльная шкала.

\section{Исходные данные для расчета экологических индексов}

Независимо от выбора методики приведения данных к сопоставимому виду и объединения их в единый интегральный индекс, исходные данные должны давать объективную картину состояния потребления ресурсов, сохранения биоразнообразия, влияния загрязнения на здоровье людей, эффективности климатической политики, а также демонстрировать области, на которых в перспективе необходимо акцентировать внимание при формировании экологической политики страны.

Выбранные данные, которые количественно определяют экологические рейтинги (за исключением Индекса загрязнения), соответствуют следующим требованиям:

- транспарентность и концептуальная ясность;

- доступность в статистических базах данных как для экспертов, так и для общественности;

- наличие достаточно больших временных рядов, позволяющих отследить изменения и тенденции в уязвимости страны по соответствующей проблематике;

- достоверность и сопоставимость.

Важно, чтобы исходные показатели собирались и поддерживались надежными и авторитетными организациями, которые проводят проверку качества своих данных. Для этого в первую очередь используется статистическая информация, аккумулируемая в базах международных организаций $(\mathrm{OOH}$, ФАО, ВОЗ, Международное энергетическое агентство, Всемирный банк, Институт мировых ресурсов и др.). В частности, можно отметить такие крупнейшие поисковые системы и базы данных, как UNdata - поисковая система, извлекающая ряды данных из статистических баз данных, собранных $\mathrm{OOH}$ и связанными с ней организациями за последние полвека; World Bank Health Nutrition 
and Population Statistics (HNPStats), в которой представлена статистика здоровья, питания и народонаселения с 1990-х годов по настоящее время, а также прогноз населения на уровне стран до 2050 г.; World Development Indicators (WDI), содержащая данные Всемирного банка о глобальном развитии, а также национальные, региональные и глобальные оценки с 1960 г.; FAOSTAT, предоставляющая доступ к данным с 1961 г. по продовольствию и сельскому хозяйству для более чем 245 стран и территорий, охватывая все региональные группы ФAO; Munich Re NatCatSERVICE - одна из самых полных в мире баз данных о стихийных бедствиях Мюнхенской инициативы по страхованию климата, содержащая сведения о всех крупных природных катастpoфах с 1950 г. и об убытках с 1980 г.

Вместе с тем эксперты отмечают достаточно большой временной лаг между доступными опубликованными данными по странам и годом составления рейтинга. Так, последние оценки экологического следа2019 основаны на данных 2017 г.; в анализ индекса экологической эффективности ЕРI 2020 не включено, например, значительное увеличение выбросов парниковых газов от обширных амазонских пожаров в 2019 г. и т. д. Соответственно и последствия пандемии COVID-19, которые бесспорно затронули все стороны жизни, включая и состояние окружающей среды, еще не отражены в представленных интегральных индексах и международных рейтингах. При этом в научных исследованиях рассматриваются такие вопросы, как корреляция между концентрацией загрязнения атмосферного воздуха и заболеваемостью/смертностью от COVID-19 (Ogen, 2020; Wu, Nethery, Sabath, Braun, Dominici, 2020); действие твердых мелкодисперсных частиц в атмосферном воздухе как переносчика вирусов на большие расстояния (Сосcia, 2020; Frontera, Martin, Vlachos, Sgubin, 2020); увеличение браконьерства и незаконной заготовки биоресурсов в условиях снижения экономической и продовольственной безопасности уязвимых групп населения ${ }^{1}$.

${ }^{1}$ Maron D.F. 2020. Poaching threats loom as wildlife safaris put on hold due to COVID-19. National Geographic. https://www.nationalgeographic.com/animals/2020/04/ wildlife-safaris-halted-for-covid-boost-poaching-threat

\section{Положение Республики Беларусь в международных әкологических рейтингах}

Обзор наиболее репрезентативных рейтинговых систем, в которых приводятся межстрановые сопоставления, позволил выявить место Беларуси по тем или иным экологическим параметрам на фоне других государств (табл. 3).

В рейтинге экологической эффективности 2020 г. Республика Беларусь занимает 49 место из 180 стран и 1 место - в группе 12 стран постсоветского пространства (за исключением Латвии, Литвы и Эстонии), показывая высокую эффективность по категории «Благоприятность окружающей среды для здоровья человека», в частности, в области обращения с отходами (1 место в группе 12 стран постсоветского пространства с баллом 77,5), качества атмосферного воздуха (2 место в группе 12 стран постсоветского пространства с баллом 49,9), уровня санитарии и качества питьевой воды (1 место в группе 12 стран постсоветского пространства с баллом 60,5). Более низкая результативность отмечается по категории «Жизнестойкость экосистем», в частности, в области поддержания экосистемных услуг (12 место в группе 12 стран постсоветского пространства с баллом 27,9), очистки сточных вод (8 место в группе 12 стран постсоветского пространства с баллом 7,2), накопления азота в почвах (8 место в группе 12 стран постсоветского пространства с баллом 45,9).

Динамика индекса экологической эффективности Беларуси за период 2016-2020 гг. отрицательная: значение индекса ЕРI 2016 82,3 (35 место в общемировом рейтинге); ЕРІ 2018 - 64,78 (44 место); ЕРI 2020 - 53,0 (49 место), что связано не столько с ухудшением экологического состояния страны, сколько с корректировкой методики расчета индекса (использование новых показателей и изменение весовой структуры).

По последним опубликованным данным (2019 г.), экологический след нашей страны составил 4,21 гга/чел. (55 место в рейтинге из 188 стран, обратное ранжирование), что в 1,5 раза превышает среднемировой показатель, а биологическая емкость 3,09 гга/чел. (37 место). Таким образом, 
Позиционирование Республики Беларусь в системах экологических рейтингов

\begin{tabular}{|c|c|c|}
\hline $\begin{array}{l}\text { Комплексный индекс /рейтинг, } \\
\text { год создания, разработчики }\end{array}$ & $\begin{array}{c}\text { Охват стран, } \\
\text { год составления }\end{array}$ & $\begin{array}{c}\text { Место Республики Беларусь среди } \\
\text { лидеров и аутсайдеров рейтинга }\end{array}$ \\
\hline $\begin{array}{l}\text { Индекс экологической эффективности } \\
\text { (Environment Performance Index), 2006, } \\
\text { Центр экологической политики и } \\
\text { права при Йельском университете } \\
\text { (США) }\end{array}$ & 180 стран, 2020 г. & $\begin{array}{l}\text { 1. Дания }(82,5) \\
\text { 2. Люксембург }(82,3) \\
\text { 3. Швейцария }(81,5) \\
\text { 49. Беларусь }(\mathbf{5 3 , 0 )} \\
\text { 178. Афганистан }(25,5) \\
\text { 179. Мьянма }(25,1) \\
\text { 180. Либерия }(22,6)\end{array}$ \\
\hline $\begin{array}{l}\text { Экологический след } \\
\text { (Ecological Footprint), 1992, НКО } \\
\text { «Глобальная сеть экологического } \\
\text { следа» }\end{array}$ & $\begin{array}{l}188 \text { стран, } 2019 \text { г. } \\
\text { (обратное ранжирование) }\end{array}$ & $\begin{array}{l}\text { 1. Катар (14,7 гга/чел.) } \\
\text { 2. Люксембург (12,8 гга/чел.) } \\
\text { 3. Арабские Эмираты }(8,9 \text { гга/чел) } \\
\text { 55. Беларусь }(\mathbf{4 , 2} \text { гга/чел.) } \\
\text { 186. Бурунди }(0,6 \text { гга/чел.) } \\
\text { 187. Йемен }(0,6 \text { гга/чел. }) \\
\text { 188. Эритрея }(0,5 \text { гга/чел.) }\end{array}$ \\
\hline $\begin{array}{l}\text { Глобальный индекс адаптации } \\
\text { к климатическим изменениям } \\
\text { (The Notre Dame Global Adaptation Index), } \\
\text { 1995, Университет Нотр-Дам (США) }\end{array}$ & $\begin{array}{l}182 \text { страны, } \\
2019 \text { г. }\end{array}$ & $\begin{array}{l}\text { 1. Норвегия }(76,8) \\
\text { 2. Новая Зеландия }(75,5) \\
\text { 3.Финляндия }(73,5) \\
\text { 37. Беларусь }(\mathbf{5 9 , 6 )} \\
\text { 180. Эритрея }(31,4) \\
\text { 181. ЦАР }(29,0) \\
\text { 182. Чад }(28,3)\end{array}$ \\
\hline $\begin{array}{l}\text { Индекс эффективности действий } \\
\text { в области изменения климата } \\
\text { (Climate Change Performance Index), } \\
\text { 2005, Европейская Сеть } \\
\text { климатических действий и НПО } \\
\text { «Немецкая Наблюдательная } \\
\text { Инициатива» (Germanwatch) } \\
\text { (Германия) }\end{array}$ & $\begin{array}{l}61 \text { страна, поставляющая } \\
90 \% \text { энергетически } \\
\text { обусловленных мировых } \\
\text { выбросов } \mathrm{CO}_{2}, 2020 \text { г. }\end{array}$ & $\begin{array}{l}\text { 4. Швеция }(75,77) \\
\text { 5. Дания }(71,14) \\
\text { 40. Беларусь }(\mathbf{4 4 , 1 8 )} \\
\text { 59. Китайский Тайбэй }(23,33) \\
\text { 60. Саудовская Аравия }(22,03) \\
\text { 61. США }(18,6)\end{array}$ \\
\hline $\begin{array}{l}\text { Индекс климатического риска, 1994, } \\
\text { НПО «Немецкая Наблюдательная } \\
\text { Инициатива» (Germanwatch) } \\
\text { (Германия) }\end{array}$ & $\begin{array}{l}180 \text { стран, 2000-2019 гг. } \\
\text { (обратное ранжирование) }\end{array}$ & $\begin{array}{l}\text { 1. Пуэрто-Рико }(7,17) \\
\text { 2. Мьянма }(10,0) \\
\text { 3. Гаити }(13,67) \\
\text { 166. Беларусь }(\mathbf{1 5 6 , 1 7 )} \\
\text { 178. Бахрейн }(170,83) \\
\text { 179. Сингапур }(172,0) \\
\text { 180. Катар }(173,67)\end{array}$ \\
\hline $\begin{array}{l}\text { Индекс загрязнения (Pollution Index), } \\
\text { 2012, Numbeo (Сербия) }\end{array}$ & 110 стран, 2020 г. & $\begin{array}{l}\text { 1. Финляндия }(11,55) \\
\text { 2. Исландия }(16,21) \\
\text { 3. Швеция }(18,09) \\
\text { 30. Беларусь }(\mathbf{4 3 , 6 3 )} \\
\text { 108. Монголия }(91,84) \\
\text { 109. Мьянма }(92,54) \\
\text { 110. Афганистан }(93,45)\end{array}$ \\
\hline
\end{tabular}

Источник. Авторская разработка на основе: URL: https://epi.yale.edu/; URL: https://www.footprintnet work.org/; URL: https://gain.nd.edu/; https://ccpi.org/; https://www.numbeo.com/

Республика Беларусь относится к группе стран-должников: общий дефищит биоемкости составляет 36\% (-1,12 гга/чел.).

Покомпонентный анализ этих показателей свидетельствует, что основным фактором дефицита биоемкости как в нашей стране, так и в мире являются антропогенные выбросы углекислого газа, связанные с использованием ископаемых видов топлива (табл. 4).
Пятилетняя динамика отражает небольшое улучшение рассматриваемых показателей: экологический след Беларуси снизился на 0,4 гга/чел.; биологическая емкость увеличилась на 0,01 гга/чел.; дефицит биоемкости уменьшился на 0,41 гга/чел. За двадцатилетний период результаты более значительны: экологический след снизился на 20,1\% (с 5,27 гга/чел. в 2000 г. до 4,21 гга/чел. в 2019 г.). 
Интегральные экологические индексы как аналитический инструмент оценки результативности...

Таблица 4

Соотношение биоемкости и экологического следа по компонентам, 2019 г.

\begin{tabular}{|l|c|c|c|c|c|c|c|}
\hline \multicolumn{1}{|c|}{ Показатель } & $\begin{array}{c}\text { Застроенная } \\
\text { земля }\end{array}$ & $\begin{array}{c}\text { Выбросы } \\
\mathrm{CO}_{2}\end{array}$ & Пашня & $\begin{array}{c}\text { Рыболовные } \\
\text { угодья }\end{array}$ & $\begin{array}{c}\text { Лесные } \\
\text { угодья }\end{array}$ & Пастбища & Итого \\
\hline \multicolumn{7}{|c|}{ Республика Беларусь } \\
\hline $\begin{array}{l}\text { Биоемкость, } \\
\text { гг/чел. }\end{array}$ & 0,06 & 0 & 1,08 & 0,02 & 1,68 & 0,25 & 3,09 \\
\hline $\begin{array}{l}\text { Экологический } \\
\text { след, гга/чел. }\end{array}$ & 0,06 & 2,02 & 0,88 & 0,08 & 1,03 & 0,14 & 4,21 \\
\hline $\begin{array}{l}\text { Экологический } \\
\text { дефицит, гга/чел. }\end{array}$ & 0 & $-2,02$ & 0,2 & $-0,06$ & 0,65 & 0,11 & $-1,12$ \\
\hline $\begin{array}{l}\text { Биоемкость, } \\
\text { гга/чел. }\end{array}$ & 0,06 & 0 & 0,52 & 0,15 & 0,68 & 0,2 & 1,61 \\
\hline $\begin{array}{l}\text { Экологический } \\
\text { след, гга/чел. }\end{array}$ & 0,06 & 1,69 & 0,52 & 0,09 & 0,27 & 0,14 & 2,77 \\
\hline $\begin{array}{l}\text { Экологический } \\
\text { дефицит, гга/чел. }\end{array}$ & 0 & $-1,69$ & 0 & 0,06 & 0,41 & 0,06 & $-1,16$ \\
\hline
\end{tabular}

Источник. Данные НКО «Глобальная сеть экологического следа» URL: https://www.footprintnetwork.org/

В последнем рейтинге стран по индексу глобальной адаптации к изменениям климата Республика Беларусь занимает 37 место из 182 стран (значение индекса NDGAIN 2019 г. - 59,6), что соответствует зеленому квадранту ND-GAIN-матрицы: страна имеет низкий уровень уязвимости к изменениям климата и высокий уровень готовности адаптироваться к климатическим изменениям. С 1995 г. (45 место) страна улучшила свою позицию в рейтинге на 8 пунктов, а по сравнению с наихудшим результатом в 2006 г. (62 место) - на 25 пунктов. Вместе с тем в рейтинге эффективности действий в области изменения климаma 2020 г. Республика Беларусь занимает невысокую позицию: 40 место из 61 страны (значение индекса СCPI - 44,18). К сожалению, по сравнению с 2019 г. (29 место в рейтинге) позиция страны ослабла; значение индекса CCPI уменьшилось на 20,7\%.

Бесспорно, Беларусь демонстрирует очень хорошие результаты в рейтингах по индексам климатического риска за 2019 г. (обратное ранжирование) и за двадцатилетие (2000-2019 гг.). Так, в первом рейтинге она входит в группу стран, занимающих 130 место, а во втором - находится на 166 месте (из 180 стран). Экстремальные погодные явления в нашей стране происходят в основном в весенне-летние месяцы в виде сильных ветров, осадков, града, тепловых волн, засухи, лесных пожаров и в редких случаях - заморозков, в последнее десятилетие они возникают чаще и становятся более интенсивными ${ }^{2}$ (Лопачук, 2020). Отметим, что значения и, следовательно, рейтинги стран по индексу климатического риска изменяются не только изза количества экстремальных погодных явлений, но и экономического положения в стране, снижения или увеличения численности населения, способности государства справляться с ущербом посредством обеспечения готовности к стихийным бедствиям и мер по смягчению их последствий, улучшения доступности оказания неотложной помощи пострадавшим.

В рейтинге по индексу загрязнения в 2020 г. Республика Беларусь заняла 30 место (значение индекса 43,63). Худшее ее положение в рейтинге было в 2015 г.: 35 место (значение индекса 45,12). Таким образом, сегодня можно говорить о некотором улучшении качества окружающей среды, которое, по задумке разработчиков индекса, проявляется прежде всего в снижении загрязнения атмосферного воздуха.

Системная организация природоохранной деятельности в целях снижения и пре-

2 Лопачук О.Н., Лысенкова М.В. 2020. Прикладные аспекты экономической оценки последствий опасных агрометеорологических явлений в Беларуси. Развитие регионального АПК и сельских территорий: современные проблемы и перспективы: материалы XVI Международной научно-практической конференции, посвященной 65-летию СибНИИЭСХ СФНЦА РАН. С. 261-263. 
дупреждения вредного воздействия антропогенной деятельности на окружающую среду, рациональное использование природных ресурсов, сохранение и устойчивое использование биологического и ландшафтного разнообразия является обязательным условием устойчивого развития страны и обеспечения ее экологической безопасности, служит гарантом результативности в природоохранной сфере. На период 20212025 гг. в Республике Беларусь поставлены достаточно высокие целевые показатели ${ }^{3}$, достижение которых позволит существенно улучшить качество окружающей среды и, соответственно, повысить положение страны в рассмотренных рейтинговых системах, в частности:

- выбросы парниковых газов - 24,5\% к уровню 1990 г. (влияние на индекс глобальной адаптации к изменениям климата и экологический след);

- индекс сброса недостаточно очищенных сточных вод в водные объекты - 50\% к уровню 2015 г. (влияние на индекс экологической эффективности);

- общая пестицидная нагрузка на почвы - не более 2,6 кг пестицидов на 1 га пашни (влияние на индекс экологической эффективности);

- доля средостабилизирующих видов земель (естественных луговых, лесных земель, земель под древесно-кустарниковой растительностью (насаждениями), под болотами, водными объектами) - не менее $58,5 \%$ от общей площади территории Республики Беларусь (влияние на индекс экологической эффективности);

- доля особо охраняемых природных территорий - не менее 9\% от общей площади территории Республики Беларусь (влияние на индекс экологической эффективности).

Структура построения интегральных экологических рейтингов соответствует схеме «тема - подтема - индикатор», что под-

${ }^{3}$ Стратегия научно-технического и инновационного развития в области охраны окружающей среды и устойчивого использования природных ресурсов на 2021-2025 годы. URL: https://minpriroda.gov.by/uploads/files/Strategijana-2021-2025-gg.pdf разумевает выделение нескольких ключевых тем, являющихся, по мнению международных экспертов, высокоприоритетными; они образуют своеобразный зонт для более узких проблемных областей, детализированных, в свою очередь, в наборе индикаторов.

Проведенное исследование дает возможность выявить отчетливый глобальный тренд: экологические параметры являются важной составляющей позиционирования страны на мировой арене. Общий рейтинг по любому интегральному индексу показывает, какие страны наилучшим образом решают те или иные экологические проблемы, что позволяет отслеживать тенденции и выявлять передовой экологический опыт.

На национальном уровне детализация и покомпонентный анализ любого индекса обладает сильным аналитическим потенциалом в понимании приоритетов природоохранной деятельности и обеспечении экологической безопасности, дает наглядную и независимую информацию для принятия решений в экологической сфере и усиления экологической политики страны.

\section{СПИСОК ЛИТЕРАТУРЫ (REFERENCES)}

Алексеева Н.Н., Аршинова М.А., Банчева А.И. 2018. Положение России в международных экологических рейтингах. Вестник Российского университета дружбы народов. Серия: Экология и безопасность жизнедеятельности. Т. 26. № 1. C. 134-152. [Alekseeva N.N., Arshinova M.A., Bancheva A.I. 2018. Position of Russia in international environmental ratings. Vestnik Rossiyskogo universiteta druzhby narodov. Seriya: Ekologiya i bezopasnost' zhiznedeyatel'nosti. Vol. 26. No 1. PP. 134-152. (In Russ.)]

Батова Н.Н. 2018. Институциональные основы и международная оценка экологической составляющей устойчивого развития. Журнал Белорусского государственного университета. Серия: Экология. № 1. С. 4-14. [Batava N.N. 2018. Institutional bases and international assessment of the ecological component of sustainable developmen. Zhurnal Belorusskogo gosudarstvennogo universiteta. Seriya: Ekologiya. No 1. PP. 4-14. (In Russ.)]

Диденко М.П. 2020. Измерение устойчивого развития: основные показатели. Экономические науки. № 11. С. 18-23. [Didenko M.P. 2020. Measuring sustainable development: key 
indicators. Ekonomicheskie nauki. No 11. PP. 1823. (In Russ.)]

Лопачук О.Н. 2020. Экономическая оценка последствий чрезвычайных ситуаций природного характера в лесном хозяйстве. Научные труды Белорусского государственного экономического универcumema. Вып. 13. С. 344-350. [Lopachuk O.N. 2020. Economic assessment of the consequences of natural emergencies in forestry. Nauchnye trudy Belorusskogo gosudarstvennogo ekonomicheskogo universiteta. Iss. 13. PP. 344-350. (In Russ.)]

Саушева О.С. 2020. Экологический след современных социально-экономических систем: измерение и тенденции. Научный журнал НИУ ИТМО. Серия: Экономика и экологический менеджмент. № 3. С. 89-97. [Sausheva O.S. 2020. Ecological footprint of modern socio-economic systems: measurement and trends. Nauchnyy zhurnal NIU ITMO. Seriya: Ekonomika $i$ ekologicheskiy menedzhment. No 3. PP. 89-97. (In Russ.)]

Borucke M., Moore D., Cranston G., Gracey K., Iha K., Larson J., Lazarus E., Morales J.C., Wackernagel M., Galli A. 2013. Accounting for demand and supply of the biosphere's regenerative capacity: The national footprint accounts' underlying methodology and framework. Ecological Indicators. Vol. 24. PP. 518-533.

Burck J., Hagen U., Höhne N., Nascimento L., Bals C. 2020. Climate change performance index. Bonn: Germanwatch. 36 p.

Chen C., Noble I., Hellmann J., Coffee J., Murillo M., Chawla N. 2015. University of Notre Dame Global Adaptation Index Country Index Technical Report. 47 p. URL: https://www. researchgate.net/publication318431802_University_ of Notre_Dame_Global_Adaptation_Index Country_Index_Téchnical_Report

Coccia $\bar{M}$. 2020. Two mechanisms for accelerated diffusion of COVID-19 outbreaks in regions with high intensity of population and polluting industrialization: The air pollution-tohuman and human-to-human transmission dynamics.
CocciaLab Working Paper. No 48B/2020. 55 p. URL: https://doi.org/10.1101/2020.04.06.20055657

Eckstein D., Künzel V., Schäfer L. 2021. Global climate risk index: Who suffers most from extreme weather events? Weather-related loss events in 2019 and 2000 to 2019. Berlin: Germanwatch. 50 p.

Ewing B., Moore D., Goldfinger S., Oursler A., Reed A., Wackernagel M. 2010. The ecological footprint atlas. Oakland, CA: Global Footprint Network. 111 p.

Frontera A., Martin C., Vlachos K., Sgubin G. 2020. Regional air pollution persistence links to COVID-19 infection zoning. Journal of Infection. URL: https://doi.org/10.1016/j.jinf.2020.03.045

Hsu A., de Sherbinin A., Esty D., Levy M. 2016. Global Metrics for the Environment: 2016. Environmental Performance Index Report. New Haven, CT: Yale University. 20 p.

Lin D., Hanscom L., Martindill J., Borucke M., Cohen L., Galli A., Lazarus E., Zokai G., Iha K., Eaton D., Wackernagel M. 2019. Working guidebook to the national footprint and biocapacity accounts. Oakland: Global Footprint Network. 73 p.

Ogen Y. 2020. Assessing nitrogen dioxide (NO2) levels as a contributing factor to coronavirus (COVID-19) fatality. Science of The Total Environment. URL: https://doi. org/10.1016/ j.scitotenv.2020.138605

Wackernagel M., Rees W. 1996. Our ecological footprint: Reducing human impact on the Earth. Gabriola Island, BC; Philadelphia, PA: New Society Publishers. 160 p.

Wendling Z. A., Emerson J. W., de Sherbinin A., Esty D.C. 2020. Environmental Performance Index 2020. Global metrics for the environment: Ranking country performance on sustainability issues. New Haven, CT: Yale Center for Environmental Law \& Policy. 220 p.

Wu X., Nethery R.C., Sabath B.M., Braun D., Dominici F. 2020. Exposure to air pollution and COVID-19 mortality in the United States: A nationwide cross-sectional study. Science Advances. 37 p. URL: https://doi. org/10.1101/ 2020.04.05.20054502 
In citation: Belorusskiy Ekonomicheskiy zhurnal. 2021. No 3. PP. 100-112.

Belarusian Economic Journal. 2021. No 3. PP. 100-112.

\section{INTEGRAL ENVIRONMENTAL INDICES AS AN ANALYTICAL TOOL FOR ASSESSING THE PERFORMANCE OF ACTIONS IN THE ENVIRONMENTAL SPHERE}

\section{Olga Lopatchouk ${ }^{1}$}

Author affiliation: ${ }^{1}$ Belarusian State Economic University (Minsk, Belarus).

Corresponding author: Olga Lopatchouk (lopachuk@mail.ru).

ABSTRACT. The article considers integral indices containing ecological parameters and systematizes them. It investigates the structure, indicators and methods of thematic ecological indices construction, which characterize the impact on the environment and human health, as well as adaptation to climate change. An overview of the sources with initial data for calculating thematic environmental indices is provided. Based on the analysis of the position of Belarus in international rankings, a range of challenges and achievements of our country in the environmental sphere is identified.

KEYWORDS: index, indicator, climatic changes, state of the environment; environmental ratings.

JEL-code: Q51, C43.

DOI: $10.46782 / 1818-4510-2021-3-100-112$

Received 7.09.2021 